\author{
Asian Journal of \\ Medical and Biological Research \\ ISSN 2411-4472 (Print) 2412-5571 (Online) \\ www.ebupress.com/journal/ajmbr
}

\title{
Article \\ Effect of dietary supplementation of ginger extract on growth, carcass
characteristics and haematological parameters in broilers
}

Sudipta Talukder, Md. Mehedi Hasan, Zakaria Al Noman, Yousuf Ali Sarker, Torun Kumar Paul and Mahmudul Hasan Sikder*

Department of Pharmacology, Bangladesh Agricultural University, Mymensingh-2202, Bangladesh

*Corresponding author: Dr. Mahmudul Hasan Sikder, Department of Pharmacology, Bangladesh Agricultural University, Mymensingh-2202, Bangladesh. E-mail: drmsikder@bau.edu.bd

Received: 07 June 2017/Accepted: 22 June 2017/ Published: 29 June 2017

\begin{abstract}
This study evaluated the effect of ginger on the growth performance, carcass quality of broiler chickens. 20 broiler chickens were randomly selected into two treatment groups identified as T1 and T2 with a positive control and a negative control group. Each treatment contained with five birds. Birds on T1 were treated with $1 \%$ ginger extract and $\mathrm{T} 2$ was treated with $2 \%$ ginger extract via drinking water. Significant variations $(p<0.05)$ existed between the control and other treatments in mean final body weight, dressed weight, daily feed intake and feed conversion ratio. At the end of experiment $\left(35^{\text {th }}\right.$ day) for $1 \%$ ginger extraction treatment the live body weight is $1746 \mathrm{gm}(\mathrm{p}<0.05)$, dressing weight $1106.4(\mathrm{p}<0.05)$ and FCR is $1.67(\mathrm{p}<0.05)$. The usage of the test ingredients had a significant effect $(p<0.05)$ on dressing percentage. Supplementation of ginger improves the performance of broilers when added at the rate of $1 \%$ of broiler ration and can be a possible alternative to antibiotic growth promoter in the feeding of broiler chicken.
\end{abstract}

Keywords: ginger; broilers; growth promoter; carcass characteristics; hematological parameters; alternative antibiotic

\section{Introduction}

Nowadays, Poultry meat is a good source of animal protein and can contribute immensely in boosting the consumption level of animal protein. The prohibitive increase in the cost of input especially that of feed is among the constraints in commercial broiler production (Madubuike and Ekenyem, 2001). Ensuring more net return and minimizing high expenditure for feed are the main challenges, for which many research strategies have been trying to address through the inclusion of feed supplements and feed additives in the diets of broiler chicken.

A major feed additive that has been extensively used is in poultry feed is antibiotics. Antibiotics use in livestock is the use of antibiotics for any purpose in the husbandry of livestock, which include not only the treatment or prophylaxis of infection but also the use of sub-therapeutic doses in animal feed to promote growth and improve feed efficiency in contemporary intensive animal farming (Ogle, 2013).

Incidentally, their use in animal feed has shown several side effects such as resistance towards the drug and evidence of resistant strains that become zoonotic (Wegener et al., 1999). Furthermore, the residue of antibiotics could be end up in human food chain if the with drawl period is not maintained.

Natural medicinal products originating from herbs and spices have been used as feed additives for farm animals (Guo, 2003). The efficacy and importance of a particular feed ingredient in poultry production is evaluated from its effect on the production performance/traits of the birds. Furthermore, valuable information can be obtained from the study of the haematological parameters. This stems from the fact that the blood serves as an important index of physiological, pathological and nutritional status of an animal. 
Ginger, Zingiber officinalis, is a perennial herbaceous plant that is a part of the Zingiberaceae family. Ginger as a carminative, diuretic, tonic and disinfectant compound contains glucosinolate, sterols and triterpenes (AlYahya, 1986). Different researchers have examined the effect of ginger on growth performance in broilers, and variable results were reported. For example, Taylor (2001) showed that the use of ginger and ginger powders significantly increased body weight and improved feed conversion compared to birds fed with control diet. In contrast, Zhang et al. (2009) examined the effect of processed ginger with different size on growth performance and showed that the ginger additive had no significant effect on the feed efficiency, while body weight and daily weight gain of birds fed with ginger supplements were higher than control group. It is also reported that serum cholesterol levels in broilers can be decrease 0.4 or $0.6 \%$ ginger powder.

The use of ginger as substitute for antibiotic growth promoters is desirable for greater productivity of poultry, increased palatability of feed, nutrient utilization, appetite stimulation, increase in the flow of gastric juice and piquancy to tasteless food (Owen and Amakiri, 2012).The present study was carried out to evaluate the growth performance, carcass quality and haematological indices of broiler chicks fed aqueous extract of ginger.

\section{Materials and Methods}

\subsection{Study location}

Collected birds were kept at poultry shed of department of pharmacology, Bangladesh Agricultural University, which is located at $24^{\circ} 43^{\prime} 10.02^{\prime \prime} \mathrm{N}, 90^{\circ} 25^{\prime} 35.42^{\prime \prime} \mathrm{E}$, and elves 45 feet. The study was lasted for 35 days started at early December 2016 and continued until mid-January 2017.

\subsection{Test ingredients}

The fresh ginger was purchased from KR Shopping centre, Bangladesh Agricultural University campus. The ginger was peeled, cut into small pieces and dried at oven at $40^{\circ} \mathrm{C}$ for 24 hours. The dried ginger was crushed by grinder (Jaipan-CM/L-7360065) and aqueous extract was prepared by Soxhletextraction as described by (Dieumou et al., 2012). After getting the extraction 1\% and 2\% solution of ginger was freshly prepared for each day.

\subsection{Experimental bird's management}

A total of 40 day-old Cobb 500 broiler chicks were purchased from Nourish Poultry \& Hatchery Limited, Gazipur, Bangladesh. The chicks were kept for nine days for acclimatization and were fed commercial broiler starter feed (Nourish poultry Feed, Nourish poultry feed limited, Gazipur, Bangladesh) only and given plain drinking water. The brooding temperature was maintained at $35^{\circ} \mathrm{C}$ during 1 st week. It was then gradually lowered by $3^{\circ} \mathrm{C}$ every week until it reached to room temperature (i.e. $25 \pm 1^{\circ} \mathrm{C}$ ). Mean initial weight of the chicks was $35.94 \mathrm{gm}$ at the start of experiment. Chicks were vaccinated with Newcastle disease vaccine (Baby Chick Ranikhet Disease Vaccine-BCRDV, Livestock Research Institute, Mohakhali, Dhaka, Bangladesh) intraocularly on $4^{\text {th }}$ day and $21^{\text {th }}$ day.

On day $7^{\text {th }}, 40$ chicks weighing average body weight of $91 \mathrm{~g}$ were randomly allotted to four treatments and a positive and negative control group in a completely randomly design (CRD). The birds were reared in iron cage of $5 \times 4 \times 3.5$ feet. Four experimental groups were identified as $\mathrm{T}_{1}\left(1 \%\right.$ ginger), $\mathrm{T}_{2}(2 \%$ ginger), $\mathrm{NC}$ (negative control: only feed and water) and PC (positive control: antibiotic (Ciprofloxacin, Renaflox®, Renata Animal Health, Dhaka, Bangladesh), Vitamin B-complex (B-comvit®, Square agrovet and pesticide, Dhaka, Bangladesh), supplied as pharmaceuticals recommended dose).

\subsection{Data collection}

Bird's weight of all groups was recorded every day. At the end of treatment, blood sample was collected from the wing vein of each bird using disposable plastic syringe and needle with an EDTA. After sacrificed dressing percentage were taken and offal's weight such as the liver, heart, pancreas, gizzard and spleen were recorded.

\subsection{Haematological assay}

The Packed Cell Volume (PCV), Total Erythrocyte Count (TEC) and Haemoglobin concentrations were done as described by Lamberg SL and Rothstein R (1977).

\subsection{Statistics and data analysis}

The data were analyzed using general linear model procedure of Statistical Package For Social Science(SPSS) IBM 20and comparison of means tested using Duncan's multiple range test and significance was considered at p<0.05 (Dieumou et al., 2012). 


\section{Results and Discussion}

The effects of feeding different concentration of dietary ginger on daily body weight gain are shown in Table 1 . All groups had initial body weight $90.75 \pm 1.35 \mathrm{~g}$. No mortality was detected in all treatment groups throughout the study period. Feed Conversion Ratio (FCR) is shown in Table 2, where significant variation was evident in $\mathrm{T}_{1}$. Dressed weights of birds are shown in Table 3. No significance variation was found in offal's weight (Table 4). Significant increases of PCV, $\mathrm{Hb}$ and TEC are shown in Table 5.

\subsection{Growth performance}

Daily body weight gain was collected in record log book. In Table 1, average weight gain from day 7 to day 35 is shown with 7 days interval. Best weight gained was observed in $\mathrm{T}_{2}$ group at day 35 followed by $\mathrm{T}_{2}, \mathrm{Pc}$ and lowest in Nc.

Table 1. Live body weight of birds from day 7 to day 35.

\begin{tabular}{llllll}
\hline \multirow{2}{*}{ Groups } & \multicolumn{5}{c}{ Body weight gain $(\mathbf{g})$} \\
\cline { 2 - 6 } & Day 7 & Day 14 & Day 21 & Day 28 & Day 35 \\
\hline $\mathbf{T}_{\mathbf{1}}$ & $89.4 \pm 5.09^{\mathrm{a}}$ & $309.6 \pm 23.86^{\mathrm{a}}$ & $754.2 \pm 56.20^{\mathrm{ab}}$ & $1351.6 \pm 83.84^{\mathrm{b}}$ & $1746.0 \pm 159.37^{\mathrm{a}}$ \\
$\mathbf{T}_{\mathbf{2}}$ & $90.6 \pm 5.09^{\mathrm{a}}$ & $332.8 \pm 23.86^{\mathrm{a}}$ & $702.0 \pm 56.20^{\mathrm{ab}}$ & $1227.2 \pm 83.84^{\mathrm{ab}}$ & $1602.0 \pm 159.37^{\mathrm{a}}$ \\
Pc & $91.0 \pm 5.09^{\mathrm{a}}$ & $311.2 \pm 23.86^{\mathrm{a}}$ & $704.0 \pm 56.20^{\mathrm{ab}}$ & $1349.0 \pm 83.84^{\mathrm{b}}$ & $1748.2 \pm 159.37^{\mathrm{a}}$ \\
Nc & $92.0 \pm 5.09^{\mathrm{a}}$ & $314.8 \pm 23.86^{\mathrm{a}}$ & $621.6 \pm 56.20^{\mathrm{a}}$ & $1119.0 \pm 83.84^{\mathrm{a}}$ & $1520.8 \pm 159.37^{\mathrm{a}}$ \\
\hline
\end{tabular}

Ginger extract given in broiler diets have significant $(\mathrm{p}<0.05)$ influence on body weight gains especially after 14 to 35 days of age. It was observed that $1 \%$ ginger was better than $2 \%$ as a supplementation to increase body weight. Farinu et al. (2004) reported slight improvement in the growth performance of broilers value (27.50\%) with ginger supplementation. On the other hand, Al-Homidan (2005) reported reduced least mean value (5.98 $\mathrm{g} / \mathrm{dl}$ ), while those on diet growth rate of broiler starters fed ginger at the rate of 20containing $1.00 \%$ garlic and $0.50 \%$ ginger mixture had higher growth rate. Javed et al. (2009) reported that broilerchicks given aqueous extract of ginger showed an improved body weight gain. Dieumou et al. (2009) found that there were no differences among the ginger oil diets and the control in terms of feed intake, body weight gain and feed conversion ratio who fed ginger essential oils to broilers. Herawati (2010) reported that hubbard strain broilers fed $2 \%$ supplemental red ginger in the diet had significantly higher final body weight than those on the control diet.

\subsection{FCR of birds}

FCR was calculated in every 7 days interval where best FCR was found in $\mathrm{T}_{1}$ group at $35^{\text {th }}$ day, followed by Pc, $\mathrm{T}_{2}$ and lees feed conversion was observed in Nc group.

Table 2. Feed Conversion Ratio (FCR) of birds on weekly basis.

\begin{tabular}{lllccl}
\hline \multirow{2}{*}{ Groups } & \multicolumn{5}{c}{ Feed Conversion Ratio (FCR) } \\
\cline { 2 - 6 } & Day 7 & Day 14 & Day 21 & Day 28 & Day 35 \\
\hline $\mathbf{T}_{\mathbf{1}}$ & 1.15 & 2.02 & 1.57 & 1.51 & 1.67 \\
$\mathbf{T}_{\mathbf{2}}$ & 1.13 & 1.91 & 1.69 & 1.67 & 1.83 \\
$\mathbf{P c}$ & 1.13 & 1.69 & 1.78 & 1.58 & 1.70 \\
$\mathbf{N c}$ & 1.11 & 1.71 & 2.01 & 1.91 & 1.88 \\
\hline
\end{tabular}

Significant $(\mathrm{P}<0.05)$ difference were revealed for FCR in all the treatments from 7 days to 35 days of age. Poor FCR was observed in negative control group and better FCR was observed in 1\% garlic group. According to Moorthy et al. (2009) and Onimisi et al. (2005) the FCR of broiler with ginger supplementation has better effect on FCR.

\subsection{Dressed weight}

After dressing of each bird at day 35, they were individually weighted. Among the groups $\mathrm{T}_{1}$ and Pc obtained highest dressed weight followed by $\mathrm{T}_{2}$ and lowest dressed weight was in Nc group (Table 3). 
Table 3. Dressed weight of birdsafter dressing at day 35.

\begin{tabular}{ll}
\hline Group & Weight of dressed birds $(\mathbf{g})$ \\
\hline $\mathbf{T}_{\mathbf{1}}$ & $1106.4 \pm 112.21^{\mathrm{ab}}$ \\
$\mathbf{T}_{\mathbf{2}}$ & $927.40 \pm 112.21^{\mathrm{a}}$ \\
$\mathbf{P c}$ & $1138.0 \pm 112.21^{\mathrm{ab}}$ \\
$\mathbf{N c}$ & $976.8 \pm 112.21^{\mathrm{ab}}$ \\
\hline
\end{tabular}

*Different letters denotes significant variation among the groups

\subsection{Offal's weight of birds}

Individual bird's liver, gizzard, hear, spleen and pancreas weight was taken and no statistical significance was observed $(\mathrm{P}<0.05)$.

Table 4. Offal's weight of birds after dressing at day 35.

\begin{tabular}{llllll}
\hline \multirow{2}{*}{ Groups } & \multicolumn{5}{c}{ Offal's weight of birds $(\mathbf{g m})}$. \\
\cline { 2 - 6 } & Liver & Gizzard & Heart & Spleen & Pancreas \\
\hline T1 & $48.64 \pm 0.65^{\mathrm{a}}$ & $9.14 \pm 1.04^{\mathrm{a}}$ & $20.85 \pm 2.69^{\mathrm{a}}$ & $3.60 \pm 0.28^{\mathrm{ab}}$ & $2.66 \pm 0.35^{\mathrm{a}}$ \\
T2 & $58.66 \pm 0.66^{\mathrm{c}}$ & $9.06 \pm 1.04^{\mathrm{a}}$ & $22.01 \pm 2.69^{\mathrm{ab}}$ & $3.37 \pm 0.28^{\mathrm{ab}}$ & $2.63 \pm 0.35^{\mathrm{a}}$ \\
Pc & $51.61 \pm 0.66^{\mathrm{a}}$ & $9.99 \pm 1.04^{\mathrm{a}}$ & $20.48 \pm 2.69^{\mathrm{a}}$ & $3.11 \pm 0.28^{\mathrm{a}}$ & $2.42 \pm 0.35^{\mathrm{a}}$ \\
$\mathrm{Nc}$ & $47.52 \pm 0.68^{\mathrm{b}}$ & $10.22 \pm 1.04^{\mathrm{a}}$ & $19.07 \pm 2.69^{\mathrm{a}}$ & $3.43 \pm 0.28^{\mathrm{ab}}$ & $2.30 \pm 0.35^{\mathrm{a}}$ \\
\hline
\end{tabular}

*Different letters denotes significant variation among the groups

The results indicated no significant differences $(\mathrm{P}<0.05)$ between all treatment groups in offal's $($ liver, gizzard, heart, spleen and pancreas) weight of bird.

\subsection{Haematological assay}

After collection of blood with anticoagulant (EDTA), TEC, Hb and PCV were performed at department of Physiology, Bangladesh Agricultural University, Mymensingh. No significance variation was found but significance increase was found among the groups but $2 \%$ ginger treated birds show relatively high PCV with least standard deviation and other hematological parameters are almost similar as positive control.

Table 5. Hematological data.

\begin{tabular}{|c|c|c|c|c|c|c|}
\hline \multirow[b]{2}{*}{ Group } & \multicolumn{3}{|l|}{ Mean } & \multicolumn{3}{|c|}{ Standard Deviation } \\
\hline & $\begin{array}{l}\text { TEC } \\
\left(\mathrm{million} / \mathrm{cm}^{3}\right)\end{array}$ & $\begin{array}{l}\mathbf{H b} \\
(\mathrm{g})\end{array}$ & $\begin{array}{l}\text { PCV } \\
(\%)\end{array}$ & $\begin{array}{l}\text { TEC } \\
\left(\mathrm{million} / \mathrm{cm}^{3}\right)\end{array}$ & $\begin{array}{l}\mathbf{H b} \\
(\mathrm{g})\end{array}$ & $\begin{array}{l}\text { PCV } \\
(\%)\end{array}$ \\
\hline $\mathrm{T}_{1}$ & 2.62 & 7.00 & 23.33 & 0.14 & 0.20 & 0.58 \\
\hline $\mathrm{T}_{2}$ & 2.86 & 7.33 & 27.00 & 0.05 & 0.12 & 1.73 \\
\hline $\mathrm{Pc}$ & 2.33 & 7.27 & 23.78 & 0.17 & 0.30 & 3.79 \\
\hline $\mathrm{Nc}$ & 2.28 & 7 & 21 & 0.17 & 0.31 & 3.79 \\
\hline
\end{tabular}

Saeid et al (2010) observed that aqeous extract of ginger significantly reduced the level of cholesterol in the blood of broilers. Bhandari et al. (1998) and Akhani et al. (2004) also reported that ginger treatment significantly decreased serum cholesterol. The present experiment didn't check cholesterol level in the blood of broiler.

\section{Conclusions}

On the basis of the performance of broilers in respect to feed intake, body weight gain, FCR and hematological data it is observed that ginger supplementation was useful in comparison to positive and negative treatment group. Although hematological data was less significant in ginger supplement group but it has significantly higher FCR and dressing percentage value as compared to other groups. Therefore, it is concluded that supplementation of ginger improves performance of broilers when added at the rate of $1 \%$ of broiler ration and can be a better alternative to antibiotic growth promoter in the feeding of broiler chicken. 
Conflict of interest

None to declare.

\section{References}

Akhani SP, SL Vishwakarma and RK Goyal, 2004. Anti-diabetic activity of Zingiber officinale in Streptozotocin-induced type I diabetic rats. J. Pharmacy Pharmacol., 56: 101-105.

Al-Homidan AA, 2005. Efficacy of using different sources and levels of Allium sativum and Zingiber officinale on broiler chicks performance. Saudi J. Bio. Sci., 12: 96-102.

Al-Yahya MA, 1986. Phytochemical studies of the plants used in traditional medicine of Saudi Arabia. Fitoterapia., 57: 179-182.

Bhandari U and JK Grover, 1998. Effect of ethanolic extract of ginger on hyperglycemic rats. Int. J. Diabetes, 6:95-96.

Dieumou FE, A Teguia, JR Kuiate, JD Tamokou, UD Doma, AUS and ECA, 2012. Effect of diets fortified with garlic organic extract and streptomycin sulphate on growth performance and carcass characteristics of broilers. Int. J. Livestock Production, 3: 36-42.

Farinu GO, SG Ademola, AO AjayiObe and GM Babatunde, 2004. Growth, haematological and biochemical studies on garlic and ginger fed broiler chickens. Moor. J. Agric. Res., 5: 122-128.

Gardzielewska J, K Pudyszak, T Majewska, M Jakubowska and J Promianowski, 2003. Effect of plant supplemented feeding on fresh and frozen storage quality of broiler chicken meat. Animal Husbandry Series of Electronic J. Polish Agric-Univ., 6(2).

Guo FC, 2003. Mushroom and herb polysaccharides as alternative for antimicrobial growth promoters in poultry(Unpublished doctoral dissertation). Wageningen University, Netherlands.

Herawati O, 2010. The effect of red ginger as phytobiotic on body weight gain, feed conversion and internal organs condition of broiler. Int. J. Poult. Sci., 9: 963-967.

Javed M, FDurrani, A Hafeez, RU Khan and I Ahmad, 2009. Effect of aqueous extract of plant mixture on carcass quality of broiler chicks. ARPN JABS, 4: 37-40.

Lamberg SL and R Rothstein, 1977. Laboratory Manual of Hematology and Urinalysis, West Port Connecticut, USA.: Avi. Publishing Company, Inc.

Madubuike FN and BU Ekeyem, 2001. Non ruminant Livestock Production in the Tropics, Gust-chuksGrapics, Owerri, Nigeria. p:185

Manseh MK, S Kazemi and M Asfari, 2012. Influence of poly germander (trucriumpolium) and watercress (Nasturtium officinale) extract on performance, carcass quality and blood metabolites of males broilers. Research Options in Animal \& Vet. Sci., 2: 66-68.

Moorthy M, S Ravi, KM Ravi and SC Edwin, 2009. Ginger Pepper and Curry Leaf Powder as Feed Additive in Broiler Diet. Int. J.Poult. Sci., 8: 779 - 782.

Ogle M, 2013. Riots, Rage, Resistance: A Brief History of How Antibiotics Arrived on the Farm. Scientific American. Retrieved November 5, 2014.

Onimisi PA, I Dafwang and JJ Omage, 2005. Growth performance and water consumption pattern of broiler chicks fed graded levels of ginger waste meal. J. Agric. Forestry and Social Sci., 3: 113-119.

Owen OJ and Amakiri, 2011. Serological and haematological profile of bitter leaf (V. Amgdalina) meal. Advances in Agri. Biotech., 1: 77-81.

Saeid JM, AB Mohamed and MA AL-Baddy, 2010. Effect of aqueous extract of ginger (zingiberofficinale) on blood biochemistry parameters of broiler. Int. J. Poult. Sci., 9: 944-947.

Taylor DJ, 2001. Effects of antibiotics and their alternatives. Br. Poult. Sci., 412: 67-687.

Wegener HC, FM Aarestrup, P Benner-Smidt and F Bager,1999. Transfer of antibiotic resistant bacteria from animal to man. Acta. Vet. Scand. Suppl., 92: 51-57.

Zhang GF, ZB Yang, Y Wang, WR Yang, SZ Jiang and GS Gai, 2009. Effects of ginger root (Zingiber officinale) processed to different particle sizes on growth performance, antioxidant status, and serum metabolites of broiler chickens. Poult. Sci., 88: 2159-2166. 